4

5

6

\title{
Severe Malaria
}

\section{Current concepts and practical overview - what every intensivist should know!}

\section{Author details}

Mervyn Mer

Department of Medicine, Divisions of Critical Care and Pulmonology, Charlotte Maxeke Johannesburg Academic Hospital and Faculty of Health Sciences, University of the Witwatersrand, Johannesburg, South Africa.

mervyn.mer@wits.ac.za

\section{Martin Dünser}

Department of Anesthesiology and Intensive Care Medicine, Kepler University Hospital and Johannes Kepler University, Linz, Austria.

\section{Martin.duenser@kepleruniklinikum.at}

\section{Regina Giera}

Department of Anesthesiology and Intensive Care Medicine, Kepler University Hospital and Johannes Kepler University, Linz, Austria.

\section{Regina.Giera@kepleruniklinikum.at}

\section{Arjen M Dondorp}

Mahidol-Oxford Tropical Medicine Research Unit (MORU), Faculty of Tropical Medicine, Mahidol University, Bangkok, Thailand

Centre for Tropical Medicine and Global Health, Nuffield Department of Medicine, University of Oxford, Oxford, United Kingdom.

\section{Arjen@tropmedres.ac}


Severe malaria is a life-threatening multi-organ disease and serious global healthcare problem. This review provides the most current concepts, contemporary issues and recent developments in the understanding and management of this potentially fatal disease and offers practical direction for all involved in the care of such patients. What every intensivist should know!

\section{Introduction and history}

Malaria is a life-threatening disease and serious global healthcare problem. It has plagued humans throughout history and has been referred to as the "King of Diseases" [1,2]. Malarial DNA going back 4000 years has been identified in Egyptian mummy tissue as well as in amber dating back more than 100 million years. Ancient works from China, India and Sumeria have also been linked with the disease and Hippocrates is credited with providing one of the first descriptions of malaria around 350-450 BC.

\section{Epidemiology and global distribution}

Malaria is a leading cause of death and disease in malaria-endemic regions such as sub-Saharan Africa, South-East Asia, the Eastern Mediterranean, Western Pacific, and South and Central America [3-5] (see Figure 1 and Table 1), as well as being an increasingly important cause of significant imported infection in non-endemic areas amongst returning travellers who have visited endemic regions [6-9]. The disease is caused by parasites of the genus Plasmodium that are transmitted to humans via the bite of infected female Anopheles mosquito vectors [1,5]. If the disease is not treated timeously, progression to severe disease with organ dysfunction and death may occur, depending on the infecting Plasmodium species and immune status of the patient [1,3,5,10-12]. Six Plasmodium species can cause malaria in humans - Plasmodium falciparum, Plasmodium vivax, Plasmodium malariae, the sympatric species Plasmodium ovale curlisi and Plasmodium ovale wallikeri, and zoonotic Plasmodium knowlesi (monkey malaria) $[1,3]$. Severe malaria is predominantly caused by $P$. falciparum but may also occur with $P$. vivax and $P$. knowlesi infections $[1,3,10]$. Approximately $1 \%$ of $P$. falciparum infections result in severe malaria which may rapidly progress to death if left untreated in non-immune individuals $[1,3,11]$. This pathogen accounts for $99 \%$ of malaria deaths, the vast majority of which occur in sub-Saharan Africa $[1,3,5]$. Criteria and definitions for severe malaria in both endemic and non-endemic settings have been defined by the World Health Organization (WHO) $[1,3,4,11,12]$ (see Table 2). In 2017 there were 87 countries and regions with ongoing malaria transmission, and malaria resulted in an estimated 219 million cases and 435000 deaths [3]. This represented an increase of 2 million cases as compared to 2016 with a similar number of deaths [3] (see Table 1). 


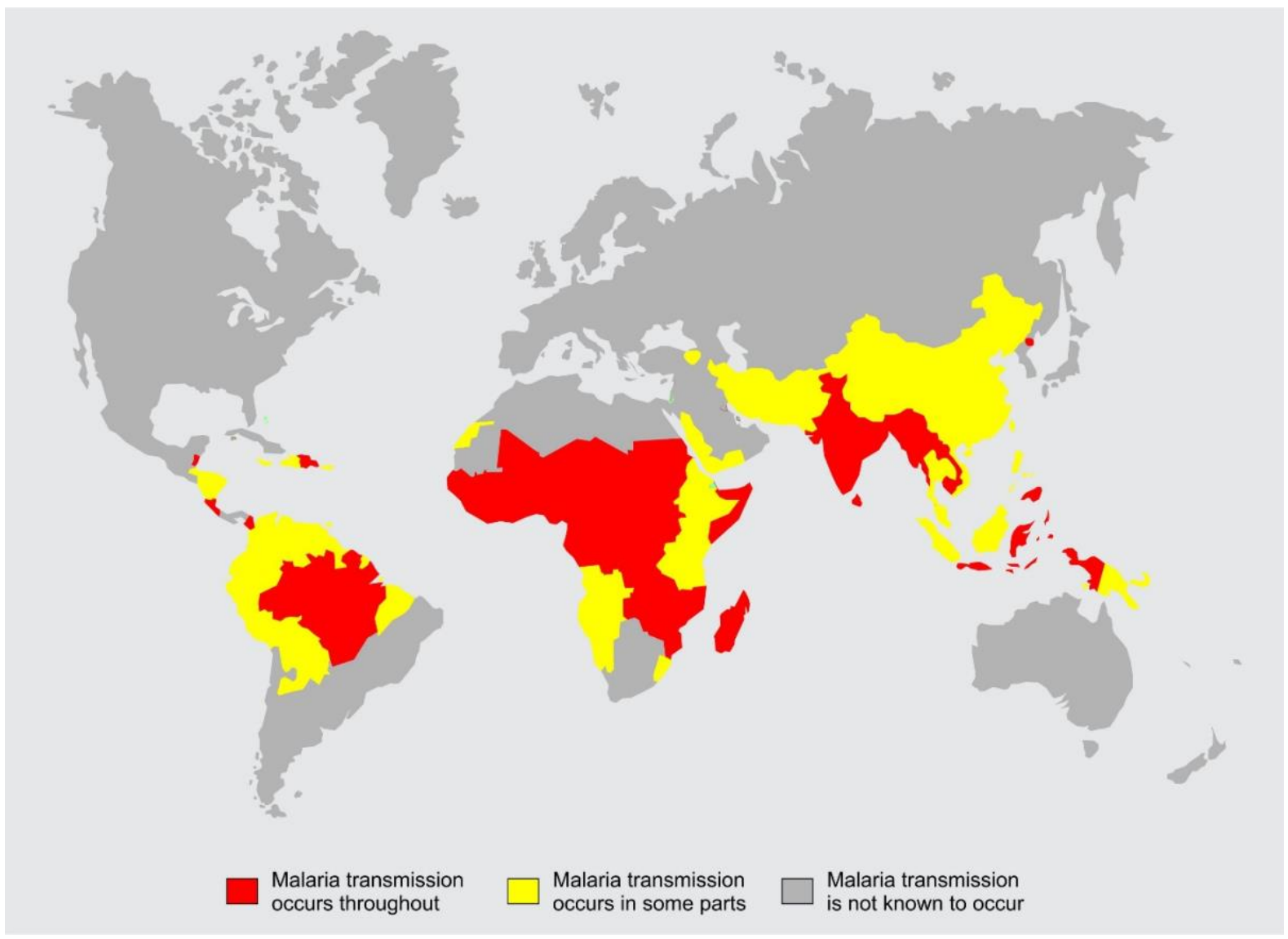

* Primary source of figure: Centers for Disease Control (CDC) and Prevention 2018 [15]

Table 1: Malaria cases and mortalities per geographic region [3]

\begin{tabular}{|l|l|l|}
\hline WHO Region & Malaria Cases & Malaria Deaths \\
\hline Africa & 200 million & 403000 \\
\hline Americas & 976000 & 630 \\
\hline Eastern Mediterranean & 4.4 million & 8300 \\
\hline South-East Asia & 11.3 million & 19700 \\
\hline Western Pacific & 1.9 million & 3620 \\
\hline World & 219 million & 435000 \\
\hline
\end{tabular}

\section{Risks and outcomes}

Approximately half the world's population is at risk of malaria. Particularly vulnerable populations at high risk of contracting malaria and developing severe malaria include infants, children under the age of 5 years, pregnant women, patients with HIV/AIDS, as well as non-immune travellers, mobile populations and migrants $[1,3,11,16]$. Partial immunity is acquired following years of exposure in endemic areas. Although this does not provide complete protection, it does importantly, reduce the risk of severe disease. Consequently, children under the age of 5 years in high transmission settings are at heightened risk of severe infection and death. In 2017, an estimated 266000 children died from malaria prior to their fifth birthday, accounting for $61 \%$ of all malaria deaths worldwide [3]. 
101

102

103

104

105

106

107

108

109

110

111

Case fatality in severe malaria varies between $5 \%$ and $50 \%$ depending on the extent of organ involvement at presentation, the availability of optimal antimalarial therapy (parenteral artesunate), and the institution of appropriate supportive measures $[1,3,4,9-12,17]$. Death usually supervenes within the first few days of admission. Survivors generally have limited or no sequelae.

Table 2. World Health Organization definition of Severe Malaria: one or more of the following conditions, in the absence of an identified alternative cause, and in the presence of Plasmodium species asexual parasitaemia [12]. 


\begin{tabular}{|c|c|c|}
\hline & Adults & Children \\
\hline \multicolumn{3}{|c|}{$\begin{array}{l}\text { Severe Malaria } \\
\text { (predominantly caused by Plasmodium falciparum; may also occur with P. vivax and P. knowlesi } \\
\text { infections) }\end{array}$} \\
\hline *Impaired consciousness & Glasgow Coma Scale $<11$ & Blantyre Coma Score $<3$ \\
\hline Prostration & \multicolumn{2}{|c|}{$\begin{array}{l}\text { generalized weakness so that the person is unable to sit, stand } \\
\text { or walk without assistance }\end{array}$} \\
\hline Multiple convulsions & \multicolumn{2}{|c|}{ more than two episodes within 24 hours } \\
\hline *Acidosis & \multicolumn{2}{|c|}{$\begin{array}{c}\text { a base deficit }>8 \mathrm{mmol} / \mathrm{L} \text {, or, if not available, a plasma } \\
\text { bicarbonate level }<15 \mathrm{mmol} / \mathrm{L} \text { or a venous lactate } \geq 5 \mathrm{mmol} / \mathrm{L}\end{array}$} \\
\hline Hypoglycaemia & \multicolumn{2}{|c|}{ blood or plasma glucose $<2.2 \mathrm{mmol} / \mathrm{L}(<40 \mathrm{mg} / \mathrm{dL})$} \\
\hline Severe malarial anaemia & $\begin{array}{l}\text { haemoglobin concentration }<7 \\
\mathrm{~g} / \mathrm{dL} \text { or a haematocrit }<20 \%\end{array}$ & $\begin{array}{l}\text { haemoglobin concentration }<5 \\
\mathrm{~g} / \mathrm{dL} \text { or a haematocrit }<15 \%\end{array}$ \\
\hline *Renal impairment & \multicolumn{2}{|c|}{$\begin{array}{c}\text { plasma or serum creatinine }>265 \mu \mathrm{mol} / \mathrm{L}(>3 \mathrm{mg} / \mathrm{dL})^{\#} \text { or blood } \\
\text { urea }>20 \mathrm{mmol} / \mathrm{L}\end{array}$} \\
\hline Jaundice & \multicolumn{2}{|c|}{$\begin{array}{l}\text { plasma or serum bilirubin }>50 \mu \mathrm{mol} / \mathrm{L}(>3 \mathrm{mg} / \mathrm{dL}) \text { with a parasite } \\
\text { count }>100,000 / \mu \mathrm{L}\end{array}$} \\
\hline Pulmonary oedema & \multicolumn{2}{|c|}{$\begin{array}{l}\text { radiologically confirmed or oxygen saturation }<92 \% \text { on room air } \\
\text { and a respiratory rate }>30 / \mathrm{min} \text {, often with chest wall indrawing } \\
\text { and crackles on auscultation }\end{array}$} \\
\hline Significant bleeding & \multicolumn{2}{|c|}{$\begin{array}{l}\text { recurrent or prolonged bleeding from the nose, gums or } \\
\text { venepuncture sites; haematemesis or melaena }\end{array}$} \\
\hline \multirow[t]{2}{*}{ Shock } & \multicolumn{2}{|c|}{$\begin{array}{l}\text { compensated shock: capillary refill time } \geq 3 \text { sec or temperature } \\
\text { gradient on leg (mid to proximal limb), but no hypotension }\end{array}$} \\
\hline & $\begin{array}{l}\text { decompensated shock: systolic } \\
\text { blood pressure }<80 \mathrm{mmHg} \\
\text { with evidence of impaired } \\
\text { perfusion (cool peripheries or } \\
\text { prolonged capillary refill time) }\end{array}$ & $\begin{array}{l}\text { decompensated shock: systolic } \\
\text { blood pressure }<70 \mathrm{mmHg} \\
\text { with evidence of impaired } \\
\text { perfusion (cool peripheries or } \\
\text { prolonged capillary refill time) }\end{array}$ \\
\hline Hyperparasitaemia & \multicolumn{2}{|c|}{ parasitaemia $>10 \%$} \\
\hline \multicolumn{3}{|c|}{ Severe Plasmodium knowlesi Malaria (two differences) } \\
\hline Jaundice & \multicolumn{2}{|c|}{$\begin{array}{l}\text { plasma or serum bilirubin }>50 \mu \mathrm{mol} / \mathrm{L}(>3 \mathrm{mg} / \mathrm{dL} \text { ) with a parasite } \\
\text { count }>20,000 / \mu \mathrm{L}\end{array}$} \\
\hline Hyperparasitaemia & \multicolumn{2}{|c|}{ parasite density $>100,000 / \mu \mathrm{L}$} \\
\hline \multicolumn{3}{|c|}{ Severe Plasmodium vivax Malaria (one difference) } \\
\hline Hyperparasitaemia & \multicolumn{2}{|c|}{ no parasite threshold included } \\
\hline
\end{tabular}

*Factors associated with strong prognostic significance - have been shown to be independent predictors of mortality $[5,17-20,30,48]$

121 \# The World Health Organization definition does not provide an adapted threshold for creatinine for paediatric populations 
During a blood feed on the human host, the infected mosquito inoculates motile sporozoites into the dermis which then travel to the liver where they multiply in hepatocytes. Subsequently, the liver schizonts burst and release 1000s of daughter merozoites which invade red blood cells where they start an asexual cycle exponentially increasing their numbers [1]. Depending on immunity, clinical symptoms develop when the number of circulating parasites reach a threshold of approximately 100 million (approximately 50 parasites/ $\mu \mathrm{L}$ blood). In contrast to Plasmodium falciparum and Plasmodium knowlesi merozoites, merozoites of Plasmodium vivax selectively invade reticulocytes and young erythrocytes explaining why parasitaemia in severe malaria due to Plasmodium vivax is typically low $(<1 \%)[1]$.

\section{Figure 2: Schematic representation of malaria lifecycle*}

\section{Sexual cycle}

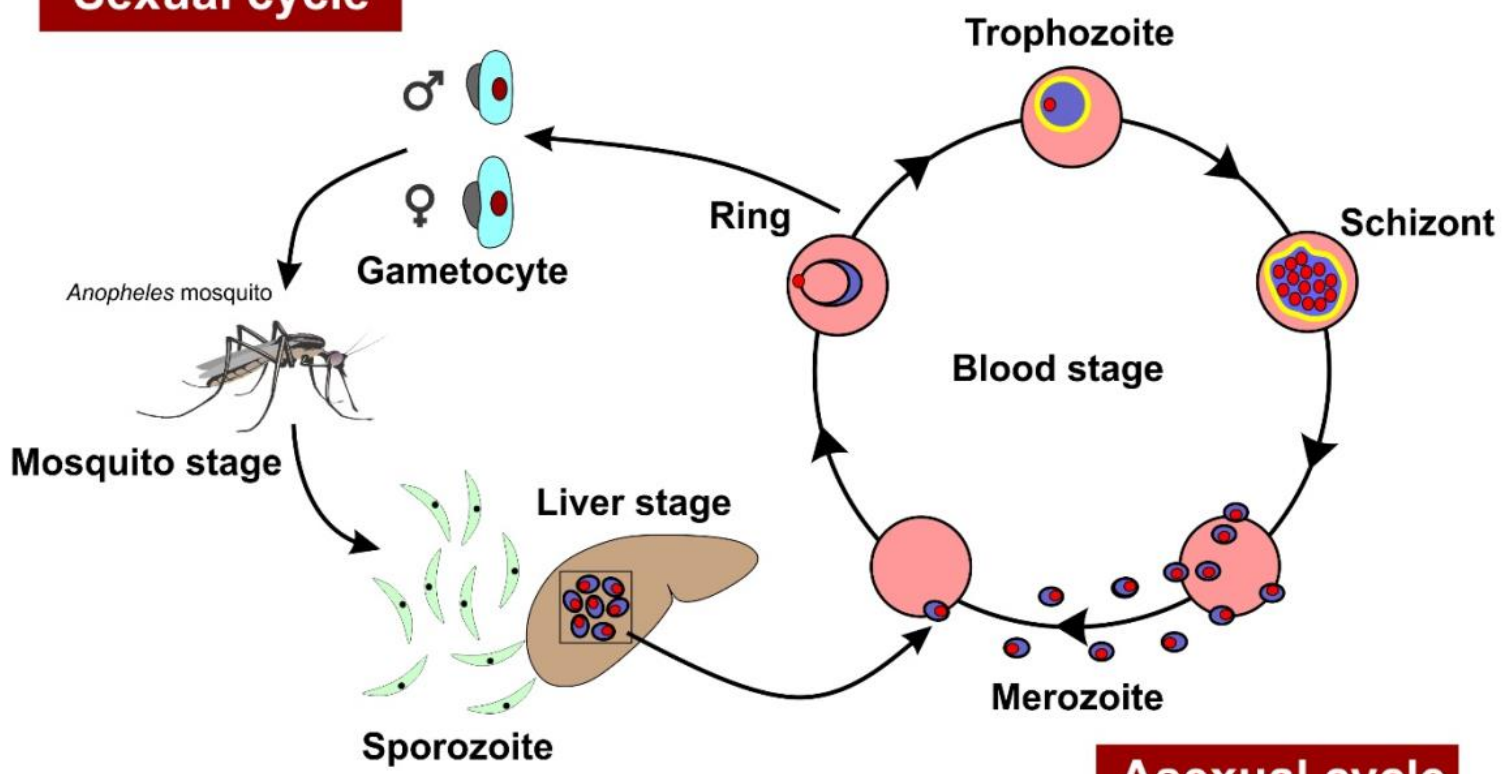

\section{Asexual cycle}

${ }^{*}$ Figure adapted and compiled from $[1,21,22]$

\section{Pathophysiology}

The development of severe malaria results from a combination of parasite-specific factors together with host inflammatory responses [23-25]. The main pathophysiological hallmark of severe malaria (as typified by $P$. falciparum malaria), is the cytoadherence and sequestration of parasitized erythrocytes to capillary and postcapillary venular endothelium of vital organs, especially in the brain, kidneys, intestines and lung [1,5,23-30]. These processes result in microvascular obstruction, impaired tissue oxygenation and metabolism, and consequent organ dysfunction [1,5,23-30]. Markers of the extent of the microvascular obstruction include plasma lactate and base deficit which are closely correlated with disease severity and prognosis [1,17-20]. Lactic acidosis results mainly from anaerobic glycolysis secondary to microcirculatory hypoperfusion. Other contributory factors to the lactic acidosis include impairment of hepatic and renal clearance $[1,23,30]$. It has also been suggested that translocation of intestinal bacteria following cytoadherence and microcirculatory 
infections, particularly in children, has been postulated to occur as a result of granulocytic phagocytosis of parasitic digestive vacuoles causing functional exhaustion, with resultant blunting of the microbiocidal activity of immune cells [32-34].

\section{Clinical Features and Presentation}

Malaria is an important cause of fever, particularly in tropical regions. The initial symptoms of the disease are non-specific and include lassitude, fatigue, headache, abdominal discomfort and muscle aches followed by irregular fever, chills and rigors [1,11]. Nausea, vomiting and orthostatic hypotension are frequent manifestations. Because the symptoms are not distinctive, severe malaria should be distinguished from other acute febrile disorders including bacterial sepsis, meningitis, viral encephalitides, viral haemorrhagic fevers such as dengue, severe influenza, leptospirosis, typhoid fever, rickettsial disorders such as typhus, viral hepatitis, intoxications and other non-infected causes of coma $[1,4,11]$.

In non-immune persons pyrexia may approach or exceed $40^{\circ} \mathrm{C}$ and be associated with tachycardia and occasionally delirium. In addition to the fever, signs of anaemia and palpable splenomegaly are often the only findings on initial physical examination. Hepatomegaly may occur, especially in young children, and jaundice is frequently noted in adults. Generalized seizures are characteristically associated with falciparum malaria and may be followed by the development of diffuse encephalopathy and coma (cerebral malaria) $[1,4,11,12,35]$. Several additional neurological signs may be present with cerebral malaria, the most common of which are dysconjugate gaze, abnormal posturing and malaria specific retinal changes $[1,4,20]$.

Various clinical features may be useful in helping to differentiate malaria from other disorders. Although headaches in malaria may be severe, they are not associated with neck stiffness or photophobia as characteristically is the case with bacterial meningitis. Myalgia is a frequent complaint in malaria but tends to be milder than that encountered in dengue, and muscle tenderness is less than may be elicited in leptospirosis or typhus. Malaria is not associated with a rash which may help to differentiate it from meningococcaemia, rickettsial infections, typhoid fever, viral exanthems and drug reactions. Cutaneous and mucous membrane petechial haemorrhages are not common in severe malaria and may be a useful clinical parameter that assists in differentiating the disorder from viral haemorrhagic fevers and leptospirosis, where such findings are more typical.

The time during which uncomplicated malaria progresses to severe malaria is variable with one study reporting the mean duration from onset of symptoms to intensive care unit admission as 5.5 days [35].

The presentation of severe malaria varies with age and the background level of acquired protective immunity $[1,17,36,37]$ (see Table 3 ). Severe anaemia, hypoglycaemia, seizures and concomitant bacterial infection are more common in children, whereas in adults, acute kidney injury, noncardiogenic pulmonary oedema (ARDS) (particularly in pregnant women) [38], and jaundice are more frequently encountered. Coma (cerebral malaria) and metabolic/lactic acidosis occur in all age groups and have strong predictive value for fatal outcome $[5,17,18,20,30]$.

The major manifestations and complications of severe malaria are discussed further under management.

Table 3 
Clinical Features and Presentation of Severe Malaria

\begin{tabular}{|l|l|l|l|}
\hline $\begin{array}{l}\text { Clinical } \\
\text { feature/complication }\end{array}$ & Adult & Children & Pregnant Women \\
\hline Anaemia & + & +++ & ++ \\
\hline Seizures & + & +++ & + \\
\hline Acute kidney injury & +++ & - & +++ \\
\hline $\begin{array}{l}\text { Non-cardiogenic } \\
\text { pulmonary oedema }\end{array}$ & ++ & + & +++ \\
\hline Jaundice & +++ & + & +++ \\
\hline Hypoglycaemia & + & +++ & +++ \\
\hline
\end{tabular}

Adapted and compiled from $[1,7,36-38]$

Key:- seldom +occasionally ++ common +++ very common

\section{Diagnosis, diagnostic work-up and considerations (see Table 4)}

Prompt and accurate diagnosis is critical to the effective management of malaria. Malaria must be excluded in any patient with a severe febrile illness acquired in a malaria endemic region and should always be a consideration in returning visitors from such regions who present with an acute febrile illness. A travel history is mandatory and an important clue to the diagnosis [6-9]. Clinical findings should always be confirmed by a diagnostic test for malaria [11-12]. Diagnostic tools include microscopy, rapid diagnostic tests (RDTs) and molecular techniques.

The World Health Organization (WHO) currently recommends prompt malaria diagnosis either by microscopy or RDT $[2,11,12,39]$.

Microscopy

Microscopy, widely regarded as the reference standard for diagnosis, involves identification of asexual forms of the parasite in suitably stained peripheral blood smears. Both thin and thick blood smears should be examined [1,2,11,12]. Microscopy allows for species identification and quantification of parasitaemia. A single negative blood smear does not exclude malaria and repeat smears should be evaluated if there is a high degree of suspicion of malaria $[4,11,12]$. In nonimmune patients, smear microscopy may underestimate the parasite biomass as most red blood cells are sequestered in the microcirculation. As a consequence, low peripheral parasite counts can still have a high total body parasite burden with a significant disease severity $[1,2,11,12]$.

These tests are simple, sensitive and quick, and detect circulating parasite-associated proteins and enzymes such as P. falciparum-specific Histidine-Rich Protein 2 (PfHRP2), lactate dehydrogenase or aldolase antigens with a drop of blood e.g. from a finger prick blood sample $[1,11,12]$. Some of the RDTs carry an additional antibody that serves to distinguish $P$. falciparum from other plasmodium species [12]. PfHRP2-based tests may remain positive for several weeks after acute infection which has been postulated to limit their usefulness in endemic areas where infections are frequent. They may however be useful in severe malaria patients who have taken antimalarial agents and cleared peripheral parasitaemia, yielding a negative malaria slide - but in whom the PfHRP2 test remains 
positive. These tests are being increasingly employed because of their ease of use, rapidity of results and similar sensitivity to microscopy $[1,2,4,11,12]$. They do not however quantify peripheral blood parasitaemia.

\section{Molecular techniques}

Molecular diagnosis by polymerase chain reaction (PCR) amplification of parasite nucleic acid is more sensitive than microscopy or RDTs for detecting low-density parasitaemia and is more accurate in speciation, but is largely used for research purposes and not universally available $[2,11,12,40]$. Loop-mediated isothermal amplification is a low technology PCR variant that has been adapted for resource-limited settings but which currently has not been deployed on a large scale. [12,40-42]

Serology involving malaria antibody measurements has no role in the diagnosis of acute malaria.

\section{Additional Tests}

In addition to the malaria specific diagnostic tests, various additional tests form part of the initial workup and include a full blood count, blood biochemistry, standard coagulation tests, repeated glucose measurements, lactate levels and blood gas analysis. These additional tests assist in determining whether the patient has manifestations of severe malaria, including severe anaemia, hypoglycaemia, renal failure, hyperbilirubinemia and acid-base disturbances.

Mild to severe anaemia as well as thrombocytopenia are almost universal findings $[1,40]$. Both anomalies are so common in severe malaria that their absence should stimulate consideration of alternative diagnoses. Hypoglycaemia is a frequent complication in malaria patients with particularly high rates among children, pregnant women, and those treated with quinine which is an insulin secretagogue [1, 4, 30, 44-46]. Metabolic acidosis and elevated blood lactate levels are both associated with heightened disease severity and an increased risk of death $[19,20,47,48]$. Low plasma albumin levels are commonly noted and have been reported to have prognostic significance in severe malaria $[11,12,49]$. Other biomarkers have been evaluated as indicators of severity and include plasma PfHRP2 and STREM-1 (soluble triggering receptor expressed on myeloid cells 1 ) but these are currently not widely available or routinely recommended [49]. Blood cultures should be performed early in patients with severe malaria to exclude bacterial bloodstream co-infection. In addition, all patients with suspected malaria should where appropriate, be checked for HIV and women of childbearing age should undergo a pregnancy test, as both conditions are associated with an increased risk of organ dysfunction and death from malaria [1,4].

Imaging studies usually reveal few abnormalities in patients with severe malaria and should be performed to answer specific diagnostic issues $[1,11,12]$. Cranial computer tomography may reveal cerebral oedema in patients with cerebral malaria and deep coma. Chest radiographs and lung ultrasonography may be useful adjuncts to help diagnose concomitant pneumonia or noncardiogenic pulmonary oedema (ARDS), and abdominal imaging may reveal splenomegaly and hepatomegaly.

\section{Table 4: Malaria Diagnosis}

\begin{tabular}{|l|l|}
\hline Component & Comments \\
\hline Clinical aspects & $\begin{array}{l}\text { Malaria is a frequent cause of fever in tropical } \\
\text { regions }\end{array}$ \\
\hline
\end{tabular}




\begin{tabular}{|c|c|}
\hline & $\begin{array}{l}\text { History of travel to an endemic area and } \\
\text { presentation with an acute febrile illness is an } \\
\text { important clue to the diagnosis. } \\
\text { Good clinical acumen can be helpful to assist in } \\
\text { differentiating malaria from a variety of other } \\
\text { tropical and important diseases and disorders. } \\
\text { Clinical findings should always be confirmed by } \\
\text { a diagnostic test for malaria }\end{array}$ \\
\hline $\begin{array}{l}\text { Microscopy } \\
\text { Blood smears peripheral blood } \\
\text {-Thin and thick films }\end{array}$ & $\begin{array}{l}\text { Microscopic examination gold standard } \\
\text { Allows species identification and quantification } \\
\text { of parasitaemia and parasite asexual stage } \\
\text { Thick films have a higher sensitivity for } \\
\text { diagnosis } \\
\text { Thin films allow more accurate speciation and } \\
\text { quantification of parasitaemia }\end{array}$ \\
\hline Rapid diagnostic tests (RDTs) & $\begin{array}{l}\text { Detect circulating parasite-associated antigens } \\
\text { Allow for the diagnosis of malaria without a } \\
\text { trained microscopist } \\
\text { Similar sensitivity to microscopy (require the } \\
\text { presence of } 100 \text { parasites/ } \mu \mathrm{L} \text { of blood to give a } \\
\text { positive result; blood smears require } 50 \\
\text { parasites/ } \mu \mathrm{L} \text { ) } \\
\text { Do not quantify parasitaemia } \\
\text { Do not usually provide speciation although the } \\
\text { PfHRP2 (Plasmodium falciparum-specific } \\
\text { Histidine-Rich Protein2) test identifies } P \text {. } \\
\text { falciparum }\end{array}$ \\
\hline Molecular techniques & $\begin{array}{l}\text { Remain largely a research tool } \\
\text { Occasionally may be useful when doubt exists } \\
\text { in infecting species to help with differentiation }\end{array}$ \\
\hline $\begin{array}{l}\text { Other clinically relevant investigations } \\
\text {-Blood (full blood count, biochemistry profile, } \\
\text { coagulation profile, glucose, blood gas analysis, } \\
\text { lactate, blood cultures) } \\
\text {-Imaging }\end{array}$ & $\begin{array}{l}\text { Assist in determining severity, identifying organ } \\
\text { dysfunction and help to guide subsequent } \\
\text { management } \\
\text { Largely used to address specific diagnostic } \\
\text { issues and directed by patient's clinical } \\
\text { condition }\end{array}$ \\
\hline
\end{tabular}


Prompt initiation of treatment with an effective parenteral antimalarial drug is pivotal in order to save lives in severe malaria. Large randomized trials have established that intravenous or intramuscular artesunate is the preferred antimalarial drug when compared to parenteral quinine for reducing mortality in both children and adults with severe falciparum malaria [48, 50-53]. It has also been shown to be associated with faster parasite clearance and reduced duration of intensive care and hospital stays [54,55]. Furthermore, artesunate is not associated with an increase in neurological sequelae in patients surviving cerebral malaria [50,51]. Artesunate is a remarkably safe drug, but an important adverse effect is so-called post-artesunate delayed haemolysis (PADH), which can cause a significant drop in haemoglobin levels one to several weeks following artesunate treatment and which occurs most commonly in non-immune travellers presenting with high parasitaemia counts [56-58]. PADH is much less common in paediatric severe malaria in moderate to high transmission areas [58]. Parenteral artesunate is now the recommended first-line treatment for severe malaria in all patient groups, including pregnant women and returning travellers $[5,11,12]$. It is also recommended for the treatment of severe $P$. vivax or $P$. knowlesi malaria $[5,11,12]$. If artesunate for injection is not available, intramuscular artemether is the second drug of choice, and intravenous or intramuscular quinine a third option $[11,12,59,60]$. Dosing regimens are listed in Table 5 . As soon as the patient is sufficiently recovered to take oral medication, parenteral treatment can be stopped, and antimalarial treatment should be completed with a full course of any artemisinin combination therapy (ACT) $[1,11,12]$. ACT with artesunate-mefloquine is not recommended and should be avoided as it is associated with post-malaria neurological syndrome [61]. In patients with severe $P$. vivax malaria, a two-week course of primaquine given in a dose of $0.25 \mathrm{mg} / \mathrm{kg}$ (or $0.5 \mathrm{mg} / \mathrm{kg}$ in parts of the Asian pacific region) daily orally is advocated to address persistent liver forms and prevent relapses (antimalarials that are active against the erythrocytic forms of the parasite do not act on the liver forms). Prior testing for glucose-6-phosphate dehydrogenase (G6PD) deficiency is recommended in these patients in view of the oxidative haemolytic potency of the drug $[4,11,12]$.

\section{Adjunctive treatments}

No adjunctive treatments are currently routinely recommended in the management of severe malaria. An exception might be paracetamol which has renoprotective properties, and has been shown in adult patients to ameliorate the oxidative effects of plasma cell-free haemoglobin, which is always elevated in severe malaria [63]. Corticosteroids are not recommended, but the evidence is based on older small trials [64]. Mannitol therapy is not beneficial in cerebral malaria and prolongs coma duration in adult patients [65]. There are no randomized trials on exchange transfusion in patients with hyperparasitaemia, but current evidence suggests no benefit [66-68]. Exchange transfusion can only clear the circulating ring stage parasitized red blood cells, whereas the more pathogenic mature stages are sequestered in the microcirculation. Artesunate confers an almost equally very rapid clearance of peripheral blood parasitaemia $[67,68]$.

\section{Treatment of concomitant diseases}


Invasive concomitant bacterial infection has been well documented in children with severe $P$. falciparum malaria [69] but is much less frequent in adult patients [70]. Addition of broad-spectrum parenteral antibiotic treatment is recommended for the treatment of paediatric severe malaria. In adult patients this is currently recommended only when there is a high index suspicion of bacterial co-infection such as in the presence of hypotensive shock or a neutrophilic leucocytosis.

\section{Supportive treatment}

Severe malaria is a sepsis syndrome, and its management largely follows the recommendations of the "Surviving Sepsis Campaign" guidelines (see Table 6). Not all the interventions discussed may be readily available in resource-limited regions and for some of the suggestions, there is a paucity of evidence. Where this is the case, recommendations based on current best clinical practice or expert opinion are provided. However, because of its unique pathophysiology, there are some important management principle differences. In particular, fluid management should be more restricted in patients with hyperlactatemia in the absence of hypotensive shock. Fluid bolus therapy in children with severe malaria and compensated shock has been shown to be detrimental, significantly increasing mortality [71]. In the absence of hypotensive shock, a maintenance crystalloid fluid therapy of 1 to $3 \mathrm{ml} / \mathrm{kg} /$ hour during the first day depending on the level of dehydration, is usually sufficient $[5,72,73]$. In cerebral malaria patients, plasma glucose should always be checked without delay, and hypoglycaemia treated immediately with continued glucose monitoring as rebound and recurrent hypoglycaemia is well documented [44-46]. In comatose patients requiring mechanical ventilation immediate airway control and controlled mechanical ventilation should be instituted. Rapid sequence intubation has been advocated by various authorities as a means to limit both aspiration and further brain swelling of the engorged brain [74-76]. This is also the rationale why permissive hypercapnia as a ventilation strategy is not recommended.

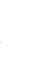

\section{Table 5}




\section{Antimalarial treatment of severe malaria}

Adults, pregnant women and children

\section{First-line initial therapy}

- Artesunate intravenously $2.4 \mathrm{mg} / \mathrm{kg}$ per dose at hour 0,12 , and 24 , then every 24 hours

- If <20 kg: artesunate intravenous $3.0 \mathrm{mg} / \mathrm{kg}$ per dose

- No dose adjustment required in renal failure

\section{Alternative initial therapy}

- Quinine dihydrochloride intravenous infusion $20 \mathrm{mg}$ salt/kg loading dose (over 4 hours) then maintenance dose $10 \mathrm{mg}$ salt/kg (over 2 hours) every 8 hours

- Administer in 5\% dextrose water with careful cardiac and glucose monitoring

- Reduce maintenance dose by one third in patients with renal failure

- Artemether intramuscular injection $3.2 \mathrm{mg} / \mathrm{kg}$ loading dose, then $1.6 \mathrm{mg} / \mathrm{kg}$ every 24 hours

After $\mathbf{2 4}$ hours and able to eat and drink

- Artemisinin-based combination therapy orally for 3 days (avoid mefloquine)

Travel history to countries with artemisinin resistance* (Cambodia, South Vietnam, Northeastern Thailand $[11,12]$

- Intravenous artesunate PLUS intravenous quinine (expert opinion, no evidence)

* artemisinin resistance has been linked to single point mutations in the "propeller" region of the $P$. falciparum kelch protein gene on chromosome 13 (kelch 13) with resultant delayed parasite clearance [62]

Table 6: Treatment and pathophysiological explanation of manifestations and complications of severe malaria 


\begin{tabular}{|c|c|c|}
\hline $\begin{array}{l}\text { Manifestations and } \\
\text { complications }\end{array}$ & Pathophysiology & Treatment \\
\hline $\begin{array}{l}\text { Coma } \\
\text { (Glasgow Coma Score }<11 ; \\
\text { Blantyre Coma Score }<3 \text { in } \\
\text { preverbal children and } \\
\text { convulsions }\end{array}$ & $\begin{array}{l}\text { Sequestration of parasitized red } \\
\text { blood cells in the cerebral } \\
\text { microcirculation and other factors }\end{array}$ & $\begin{array}{l}\text { Hypoglycemia and other causes of } \\
\text { meningo/encephalitis should be } \\
\text { excluded } \\
\text { Good general intensive nursing care, } \\
\text { including close observation of } \\
\text { breathing, eye care } \\
\text { Place nasogastric tube and urinary } \\
\text { catheter } \\
\text { If feasible: intubation to protect } \\
\text { airway } \\
\text { Frequent monitoring of blood } \\
\text { glucose; Treat convulsions }\end{array}$ \\
\hline $\begin{array}{l}\text { Anaemia } \\
\text { (Haematocrit <20\%, in } \\
\text { presence of parasitaemia } \\
>100000 / \mu \mathrm{L} \text { ) }\end{array}$ & $\begin{array}{l}\text { Loss of parasitized red blood cells, } \\
\text { increased splenic clearance of } \\
\text { uninfected red blood cells } \\
\text { (decreased red cell deformability, } \\
\text { possible immunologic factors), } \\
\text { dyserythropoiesis }\end{array}$ & $\begin{array}{l}\text { General recommendation: } \\
\text { transfusion if in distress (severe } \\
\text { tachycardia, respiratory distress } \\
\text { metabolic acidosis, active bleeding, } \\
\text { other severity symptoms), or } \\
\text { Haematocrit }<20 \% \text { (adults), or } \\
\text { Haemoglobin }<5 \mathrm{~g} / \mathrm{dL} \text { in children }\end{array}$ \\
\hline $\begin{array}{l}\text { Hyperparasitaemia } \\
\text { (>10\% infected red blood } \\
\text { cells) }\end{array}$ & $\begin{array}{l}\text { Host immunologic factors and } \\
\text { parasite virulence factors } \\
\text { (multiplication rate, red cell } \\
\text { selectivity) }\end{array}$ & $\begin{array}{l}\text { Start parenteral antimalarial drugs } \\
\text { promptly in effective doses } \\
\text { (artesunate; if quinine: give loading } \\
\text { dose) } \\
\text { Exchange transfusion controversial - } \\
\text { done in some centres (no clear } \\
\text { benefit appears to exist when } \\
\text { treating with i.v. artesunate) [66-68] }\end{array}$ \\
\hline $\begin{array}{l}\text { Hypoglycaemia } \\
\text { (blood glucose }<54 \\
\mathrm{mg} / \mathrm{dL} \text { ); }<3 \mathrm{mmol} / \mathrm{L} \text { ) }\end{array}$ & $\begin{array}{l}\text { Increased use, possible decreased } \\
\text { production } \\
\text { Quinine-related hyperinsulinism }\end{array}$ & $\begin{array}{l}\text { Glucose } 10 \%, 4 \mathrm{mg} / \mathrm{kg} \text { bodyweight } \\
\text { administered immediately. Check } \\
\text { glucose thereafter and ongoing } \\
\text { glucose monitoring essential [44-46] }\end{array}$ \\
\hline $\begin{array}{l}\text { Acute renal failure } \\
\text { (plasma creatinine }>3 \\
\mathrm{mg} / \mathrm{dl} ;>265 \mu \mathrm{mol} / \mathrm{l}) \text {, or } \\
\text { elevation } 1.5 \times \text { baseline } \\
\text { within } 7 \text { days }\end{array}$ & $\begin{array}{l}\text { Acute tubular necrosis } \\
\text { Pre-renal component } \\
\text { (dehydration) }\end{array}$ & $\begin{array}{l}\text { Record input/output (Foley } \\
\text { catheter); Check biochemistry (BUN, } \\
\text { electrolytes), start or transfer for } \\
\text { renal replacement therapy } \\
\text { (haemofiltration or haemodialysis } \\
\text { preferred over peritoneal dialysis - } \\
\text { better outcomes reported [77] }\end{array}$ \\
\hline $\begin{array}{l}\text { Severe jaundice } \\
\text { (bilirubin }>3.0 \mathrm{mg} / \mathrm{dL} \text { or } 50 \\
\mu \mathrm{mol} / \mathrm{L} \text {, with parasitaemia } \\
>100000 / \mu \mathrm{L} \text { ) }\end{array}$ & $\begin{array}{l}\text { Mainly in adults; multifactorial - } \\
\text { haemolysis, hepatocyte injury, } \\
\text { cholestasis }\end{array}$ & $\begin{array}{l}\text { No specific treatment; Monitor } \\
\text { blood glucose; patients may remain } \\
\text { jaundiced if ongoing renal } \\
\text { dysfunction }\end{array}$ \\
\hline $\begin{array}{l}\text { Fluid/electrolyte } \\
\text { imbalances, metabolic } \\
\text { acidosis } \\
\text { (venous plasma } \\
\text { bicarbonate }<15 \mathrm{mmol} / \mathrm{L} \\
\text { or lactate }>4 \mathrm{mmol} / \mathrm{L} \text { ) }\end{array}$ & $\begin{array}{l}\text { Dehydration, possible SIADH; Only } \\
\text { minor increase in capillary } \\
\text { permeability, compromised } \\
\text { microcirculation by sequestration } \\
\text { and other factors causing } \\
\text { anaerobic glycolysis }\end{array}$ & $\begin{array}{l}\text { Careful fluid resuscitation } \\
\text { Bicarbonate administration only if } \\
\mathrm{pH}<7.15 \\
\text { Dialysis as treatment for severe } \\
\text { acidosis has been advocated }\end{array}$ \\
\hline $\begin{array}{l}\text { Respiratory distress and } \\
\text { pulmonary edema }\end{array}$ & $\begin{array}{l}\text { Acidosis-related deep breathing } \\
\text { Pulmonary oedema (ARDS) mainly } \\
\text { in adults and pregnant women }\end{array}$ & $\begin{array}{l}\text { See also acidosis } \\
\text { ARDS: do not overfill, positive } \\
\text { pressure lung protective mechanical }\end{array}$ \\
\hline
\end{tabular}




\begin{tabular}{|l|l|l|}
\hline & $\begin{array}{l}\text { Aetiology unknown; possibly } \\
\text { cytokine mediated with increased } \\
\text { pulmonary permeability. Typically } \\
\text { occurs several days after initiation } \\
\text { of antimalarial treatment and } \\
\text { parasite clearance [38] }\end{array}$ & $\begin{array}{l}\text { ventilation with PEEP, appropriate } \\
\text { driving pressures, tidal volumes etc. } \\
\text { Do not allow 'permissive } \\
\text { hypercapnia' (brain swelling) } \\
\text { Distinguish from pneumonia }\end{array}$ \\
\hline Blackwater fever & $\begin{array}{l}\text { Related to severe malaria, quinine } \\
\text { use and G6PD deficiency. } \\
\text { Haemolysis with haemoglobinuria } \\
\text { [78] }\end{array}$ & $\begin{array}{l}\text { Transfusion if needed } \\
\text { Consider bicarbonate administration } \\
\text { Consider paracetamol as } \\
\text { renoprotective therapy }\end{array}$ \\
\hline $\begin{array}{l}\text { Circulatory shock } \\
\text { (systolic BP <90 mmHg [80 } \\
\text { mmHg in children] with } \\
\text { cold extremities) }\end{array}$ & $\begin{array}{l}\text { Uncommon in severe malaria may } \\
\text { (may be related to nitric oxide } \\
\text { binding by free haemoglobin) } \\
\text { Consider concurrent bacteraemia }\end{array}$ & $\begin{array}{l}\text { Fluids, inotropic drugs (adrenaline } \\
\text { [epinephrine] may potentially } \\
\text { worsen lactic acidosis), antibiotics }\end{array}$ \\
\hline Abnormal bleeding & $\begin{array}{l}\text { Diffuse intravascular coagulation: } \\
\text { consider concomitant sepsis } \\
\text { Isolated thrombocytopenia (very } \\
\text { common) - splenic sequestration, } \\
\text { dysthrombopoeisis, perhaps } \\
\text { endothelial binding and lysis [1,40] }\end{array}$ & $\begin{array}{l}\text { No specific treatment. Correction of } \\
\text { coagulation factors and platelet } \\
\text { transfusion in severe bleeding. } \\
\text { Packed red cell transfusion if } \\
\text { indicated }\end{array}$ \\
\hline $\begin{array}{l}\text { Postartesunate delayed- } \\
\text { onset hemolysis (PADH) } \\
\text { infected ("pitted") erythrocytes, } \\
\text { related to the parasite clearance } \\
\text { mechanism after artesunate } \\
\text { treatment in non-immune patients }\end{array}$ & $\begin{array}{l}\text { Follow up of haemoglobin level up } \\
\text { to 1 month after artesunate } \\
\text { treatment in non-immune patients, } \\
\text { in particular those presenting with } \\
\text { high ring stage parasitaemia [56-58] }\end{array}$ \\
\hline
\end{tabular}

\section{Preventive Measures}

Prevention of malaria focuses on three main strategies that include vaccination, vector control and chemoprophylaxis. Currently, vaccines against malaria show acceptable safety but only moderate efficacy, with $30 \%$ protection being demonstrated against malaria in infants during the 12 months following the last dose [79]. Key elements of vector control include mosquito nets (particularly pyrethroid-insecticide-treated nets), use of appropriate clothing (i.e. wearing of long sleeves and long trousers, particularly between dusk and dawn, as the Anopheles mosquito vector tends to bite at night), insect repellents, and indoor residual spraying with insecticides ${ }^{1}$. Avoiding and addressing stagnant pools of water also ameliorates the presence of mosquitoes which thrive in these situations. Chemoprophylaxis is recommended for travellers with potential exposure to malaria. It is important to remember that no chemoprophylaxis is completely reliable, and that malaria should always also be considered in febrile patients who have travelled to malaria endemic regions even if they have taken chemoprophylaxis $[1,4,9]$.

\section{Conclusion}

It is incumbent on all health care workers involved in acute and critical care, irrespective of geographic location, to have a working knowledge and current understanding of the contemporary concepts, principles, and management aspects pertaining to this highly relevant, potentially devastating and impactful disease. A malaria memoir is provided in Table 7. 
Table 7

\section{Malaria memoir - 10 pivotal principles and practical pointers}

- Malaria is a serious global healthcare problem, with approximately half the world's population living in areas at risk of malaria transmission

- The most vulnerable individuals are those with little or no immunity against the disease and include young children, pregnant women, travellers and migrants from areas with low or no malaria transmission

- Severe malaria is a medical emergency characterized by multi-organ disease

- A diagnosis of severe malaria should be considered in all patients with severe febrile illness, illness acquired in a malaria endemic area, or in those with a history of travel. A travel history should always be obtained from patients presenting with febrile illness.

- Severe malaria and malaria mortality is mainly caused by Plasmodium falciparum, but both $P$. vivax and $P$. knowlesi can also cause severe disease

- Microcirculatory impairment caused by sequestration of parasite-infected erythrocytes, red cell rigidity and red cell clumping, differentiates severe malaria pathophysiologically from bacterial sepsis

- Early diagnosis (confirmed by microscopy or rapid diagnostic testing) and treatment is essential to prevent disease progression and limit mortality in severe malaria

- Parenteral artesunate is the drug of choice to treat severe malaria in all patient groups, including children, pregnant women and travellers

- Presenting manifestations with the strongest prognostic significance are coma (cerebral malaria), metabolic (lactic) acidosis and renal dysfunction.

- The most common pitfalls to avoid in the management of severe malaria include delay of initiation of antimalarial treatment, failure to recognize hypoglycaemia, and overly zealous fluid administration in patients without hypotension (cautious and judicious fluid administration is advised in these patients to prevent potentially lethal pulmonary oedema) 
1. White NJ, Pukrittayakamee, Hien TT, Faiz MA, Mokuolu OA, Dondorp AM (2014). Malaria. Lancet 383: 723-735

2. Tangpukdee N, Duangdee C, Wilairatana P, Krudsood S (2009). Malaria Diagnosis: A Brief Review. Korean J Parasitol 47(2): 93-102

3. World Malaria Report 2018. Geneva: World Health Organization; 2018. Licence: CC BY-NC-SA 3.0 IGO

4. Karnad DR, Nor MBM, Richards GA, Baker T, Amin P; on behalf of the Council of the World Federation of Societies of Intensive and Critical Care Medicine (2018). Intensive care in severe malaria: Report from the task force on tropical diseases by the World Federation of Societies of Intensive and Critical Care Medicine. J Crit Care 43: 356-360

5. Dondorp AM, Hoang MNT, Mer M (2017). Sepsis in Resource-Limited Settings-Expert Consensus Recommendations Group of the European Society of Intensive Care Medicine (ESICM) and the Mahidol-Oxford Research Unit (MORU) in Bangkok, Thailand Recommendations for the management of severe malaria and severe dengue in resourcelimited settings. Intensive Care Med 43(11): 1683-1685

6. Odilini S, Parola P, Gkrania-Klotsas E, Caumes E, Schlagenhauf P, Lopez-Velez R, Burchard GD, Santos-O'Connor F, Weld L, von Sonnenburg F, Field V, de Vries P, Jensenius M, Loutan L, Castelli F (2012). Travel-related important infections in Europe, EuroTravNet 2009. Clin Microbiol Infect 18: 468-7

7. Leder K, Torresi J, Libman MD, Cramer JP, Castelli F, Schlagenhauf P, Wilder-Smith A, Wilson $\mathrm{ME}$, Keystone JS, Schwartz E, Barnett ED, von Sonnenburg F, Browstein JS, Cheng AC, Sotir MJ, Esposito DH, Freedman DO; GeoSentinel Surveillance Network (2013). Geosentinel surveillance of illness of returned travellers, 2007-2011. Ann Intern Med 158: 456-68

8. Jensenius M, Han PY, Schagenhauf P, Schwartz E, Parola P, Castelli F, von Sonnenburg, Loutau L, Leder K, Freedman DO (2013). Acute and potentially life-threatening diseases in western travellers - a GeoSentinel multicentre study 1996-2011. Am J Trop Med Hyg 88(2): 397-404

9. Marks M, Gupta-Wright A, Doherty JF, Singer M, Walker D (2014). Managing malaria in the intensive care unit. Brit J Anaesth 113(6): 910-21

10. Trivedi T, Bajaj P, Moulick N, Padwal N (2014). Mortality in malaria: Intensive care (MIMIC). J Assoc Physicians India 66: 16-20

11. Severe malaria (2014). Trop Med Int Health; 19 Suppl 1: 7-131. World Health Organization. Guidelines for the treatment of malaria (2015). Third Edition. World Health Organization.

12. World Health Organization. Guidelines for the treatment of malaria (2015). Third Edition. World Health Organization

13. World Health Organization. Global Health Observatory (GHO) data. Available at www.int/gho/malaria/en. Accessed 11 August 2019

14. Gething PW, Patil AP, Smith DL, Guerra CA, Elyazar IRF, Johnston GL, Tatem AJ, Hay SI (2011). A new world malaria map: Plasmodium endemicity in 2010. Malaria Journal 10: 378

15. Centres for Disease Control and Prevention. Where malaria occurs. Available at https://www.cdc.gov/malaria/about/distribution.html. Accessed 11 August 2019

16. Pasvol G (2005). Management of severe malaria: interventions and controversies. Infect Dis Clin North Am 19: 211-40

17. Dondorp AM, Lee SJ, Faiz MA, Mishra S, Price R, Tjitra E, Than M, Htut $Y$, Mohanty S, Yunus ER, Rahman R, Nosten F, Anstey NM, Day NP, White NJ (2008). The relationship between age and the manifestations of mortality associated with severe malaria. Clin Infect Dis 47(2): 151-7

18. Von Seidlein L, Olaosebikan R, Hendriksen IC, Lee SJ, Adedoyin OT, Agbenyega T, Nguah SB, Bojang K, Deen JL, Evans J, Fanello Cl, Gomes E, Pedro AJ, Kahabuka C, Karema C, Kivaya E, 
Maitland K, Mokuolu OA, Mtove G, Mwanga-Amumpaire J, Nadim B, Nansumba M, Ngum WP, Onyamboko MA, Reyburn H, Sakulthaew T, Silamut K, Tshefu AK, Umulisa N, Gesase S, day NP, White NJ, Dondorp AM (2012). Predicting the clinical outcome of severe falciparum malaria in African children: findings from a large randomized trial. Clin Infect Dis 54(8): 108090

19. Day NP, Phu NH, Mai NT, Chau TT, Loc PP, Chuong LV, Sinh DX, Holloway P, Hien TT, White NJ (2000). The pathophysiologic and prognostic significance of acidosis in severe adult malaria. Crit Care Med 28: 1833-1840

20. Plewes K, Turner GDH, Dondorp AM (2018). Pathophysiology, clinical presentation, and treatment of coma and acute kidney injury complicating falciparum malaria. Curr Opin Infect Dis 31: 69-77

21. Enomoto M, Kawazu S-I, Kawai S, Furuyama W, Ikegami T, Wantanabe J, Mikoshiba K (2012). Blockage of spontaneous $\mathrm{Ca}^{2+}$ oscillation causes cell death in intraerythrocytic Plasmodium falciparum. PLoS ONE 7(7): e39499

22. Centres for Disease Control and Prevention. Biology: Lifecycle. Available at https://www.cdc.gov/malaria/about/biology/index.html. Accessed 11 August 2019

23. MacKintosh CL, Beeson JG, Marsh K (2004). Clinical features and pathogenesis of severe malaria. Trends Parasitol 20(12): 597-603

24. Miller LH, Good MF, Milon G (1994). Science 264(5167): 1878-1883

25. Milner DA Jr. Malaria Pathogenesis (2018). Cold Spring Harb Perspec Med 8(1). pii: a025569

26. Dondorp AM (2008). Clinical significance of sequestration in adults with severe malaria. Transfus Clin Biol 15(1-2): 56

27. Ponsford MJ, Medana IM, Prapanslip P, Hien TT, Lee SJ, Dondorp AM, Esiri MM, Day NP, White NJ, Turner GD (2012). Sequestration and microvascular congestion are associated with coma in human cerebral malaria. J Infect Dis 205(4):663-71

28. Newbold C, Craig A, Kyes S, Rowe A, Fernandez-Reyes D, Fagan T (1999). Cytoadherence, pathogenesis and the infected red cell surface in Plasmodium falciparum. Int $J$ Parasitol 29(6): 927

29. Wassmer SC, Taylor TE, Rathod PK, Mishra SK, Mohanty S, Arevalo-Herrera M, Duraisingh MT, Smith JD (2015). Investigating the pathogenesis of severe malaria: a multidisciplinary and cross-geographical approach. Am J Trop Med Hyg 93(3 Suppl): 42

30. Krishna S, Waller DW, ter Kuile F, Kwiatkowski D, Crawley J, Craddock CFC, Nosten F, Chapman D, Brewster D, Holloway PA, White NJ (1994). Lactic acidosis and hypoglycaemia in children with severe malaria: pathophysiological and prognostic significance. Trans $R$ Soc Trop Med Hyg 88(1): 67-73

31. Krishnan A, Karnad D (2003). Severe falciparum malaria: An important cause of multiple organ failure in Indian intensive care unit patients. Crit Care Med 31: 2278-2284

32. Dascari P, Reiss K, Lingelbach K, Baumeister S, Lucius R, Udomsangpetch R, Bhakdi SC, Bhakdi $S$ (2011). Digestive vacuoles of Plasmodium falciparum are selectively phagocytosed by and impair killing function of polymorphonuclear leukocytes. Blood 118: 4946-4956

33. English M, Punt J, Mwangi I, McHugh K, Marsh K (1996). Clinical overlap between malaria and severe pneumonia in African children in hospital. Trans $R$ Soc Trop Med Hyg 90: 658-662

34. Bronzan RF, Taylor TE, Mwenechanya J, Tembo M, Kayira K, Bwanaisa L, Njobvu A, Kondowe W, Chalira C, Walsh AL, Phiri A, Wilson LK, Molyneux ME, Graham SM (2007). Bacteremia in Malawian children with severe malaria: prevalence, etiology, HIV co-infection, and outcome. J Infect Dis 195: 895-904

35. Bruneel F, Tubach F, Corne P, Megarbane B, Mira JP, Peytel E, Camus C, Schortgen F, Azoulay E, Cohen Y, Georges H, Meybeck A, Hyvernat H, Trouillet JL, Frenoy E, Nicolet L, Roy C, Durand R, Le Bras J, Wolff M (2010). Severe Imported Malaria in Adults (SIMA) Study Group. 
Severe imported falciparum malaria: a cohort study in 400 critically ill adults. PLoS One 5: e13236

36. Trampuz A, Jereb M, Muzlovic I, Prabhu RM (2003). Clinical review: Severe malaria. Critical Care 7: 315-323

37. Njuguna PW, Newton CR (2004). Management of severe falciparum malaria. J Postgrad Med 50: $45-50$

38. Taylor WRJ, Hanson J, Turner GDH, White NJ, Dondorp AM (2012). Respiratory manifestations of malaria. Chest 142: 492-505

39. World Health Organization. World malaria report 2019. Available at https://www.who.int/publications-detail/world-malaria-report-2019. Accessed 4 December $\underline{2019}$

40. Plewes K, Leopold SJ, Kingston HWF, Dondorp AM (2019). What's new in the management of malaria? Infect Dis Clin N Am 33: 39-60

41. Abdul-Ghani R, Al-Mekhlafi AM, Karanis $P$ (2012). Loop-mediated isothermal amplification (LAMP) for malarial parasites of humans: Would it come to clinical reality as a point-of-care test? Acta Tropica 122: 233-240

42. Euan-Taek Han (2013). Loop-mediated isothermal amplification test for the molecular diagnosis of malaria. Expert Review of Molecular Diagnostics 13:2, 205-218

43. Mohon AN, Getie S, Jahan N, Alam MS, Pillai DR (2019). Ultrasensitive loop-mediated isothermal amplification (US-LAMP) to detect malaria for elimination. Malar J 18: 350

44. Madrid L, Lanaspa M, Maculuve SA, Bassat Q (2015). Malaria-associated hypoglycaemia in children. Expert Rev Anti Infect Ther 13: 267-277

45. White NJ, Warrell DA, Chanthavanich P, Looareesuwan S, Warrell MJ, Krishna S, Williamson $\mathrm{DH}$, Turner RC (1983). Severe hypoglycaemia and hyperinsulinaemia in falciparum malaria. $N$ Engl J Med 309(2): 61-6

46. Phillips RE (1989). Hypoglycaemia is an important complication of falciparum malaria. Q J Med 71(266): 477-83

47. Hanson J, Lee SJ, Mohanty S, Faitz MA, Anstey NM, Charunwatthana P, Yunus EB, Mishra SK, Tjitra E, Price RN, Rahman R, Nosten F, Htut Y, Hoque G, Hong Chau TT, Hoan Phu N, Hien TT, White NJ, Day NP, Dondorp AM (2010). A simple score to predict the outcome of severe malaria in adults. Clin Infect Dis 50: 679-685

48. Leopold SJ, Watson JA, Jeeyapant A, Simpson JA, Phu NH, Hien TT, Day NPJ, Dondorp AM, White NJ (2019). Investigating causal pathways in severe falciparum malaria: A pooled retrospective analysis of clinical studies. PLoS Med 16(8): e10002858

49. Bruneel F, Tulbach F, Mira JP, Houze S, Gibot $S$, Huisse MG, Megarbane B, Choquet $C$, Corne P, Peytel E, Villiers D, Camus C, Bouchaud O, Caumes E, Girard PM, Simon F, Kalloumeh A, Roy C, Durand R, Le Bras J, Matheron S, Wolff M; PALUREA study Group (2016). Imported falciparum malaria in adults: host-and parasite related factors associated with severity. The French prospective multicentre PALUREA cohort study. Intensive Care Med 42(10): 15881596

50. Dondorp A, Nosten F, Stepniewska K, Day N, White N (2005). Artesunate versus quinine for treatment of severe falciparum malaria: a randomised trial. Lancet 366(9487): 717-25

51. Dondorp AM, Fanello Cl, Hendriksen IC, Gomes E, Seni A, Chhaganial KD, Bojang K, Olaosebikan R, Anunobi N, Maitland K, Kivaaya E, Agbenyega T, Nguah SB, Evans J, Gesase S, Kahabuka C, Mtove G, Nadjm B, Deen J, Mwanga-AmumpaireJ, Nansumba M, Karema C, Umulisa N, Uwimana A, Mokuolu OA, Adenyon OT, Johnson WB, Tshefu AK, Onyamboko MA, Sakulthaew T, Ngum WP, Silamut K, Stepniewska K, Woodrow CJ, Bethell D, Wills B, Oneko M, Peto TE, von Seidlein L, Day NP, , White NJ; AQUAMAT group (2010). Artesunate versus 
quinine in the treatment of severe falciparum malaria in African children (AQUAMAT): an open-label, randomised trial. Lancet 376(9753): 1647-57

52. Sinclair D, Donegan, Lalloo DG (2011). Artesunate versus quinine for treating malaria. Cochrane Database Syst Rev (3): CD005967

53. Sinclair D, Donegan S, Isba R, Lalloo DG. Artesunate versus quinine for treating severe malaria. Cochrane Database Syst Rev (6): CD005967

54. Kurth F, Develoux M, Mechain M, Clerinx J, Antorini S, Gjorup IE, Gascon J, Morch K, Nicastri E, Ramharter M, Bartoloni A, Visser L, Rolling T, ZangerP, Calleri G, Salas-Coronas J, Nielsen $H$, Just-Nubling $G$, Neumayr $A$, Hachfeld $A$, Schmid ML, Antonini $P$, Pongratz $P$, Kern $P$, Saraiva da Cunha J, Soriano-Arandes A, Schunk M, Suttorp N, Hatz C, Zoller T; TropNet Severe Malaria Investigator Group (2015). Intravenous artesunate reduces parasite clearance time, duration of intensive care, and hospital treatment in patients with severe malaria in Europe: the TropNet Severe Malaria Study. Clin Infect Dis 61(9): 1441-4

55. Eder M, Farne H, Cargill T, Abbara A, Davidson RN (2012). Intravenous artesunate versus intravenous quinine in the treatment of severe falciparum malaria: a retrospective evaluation from a UK centre. Pathog Glob Health 106(3): 181-7

56. Jaureguiberry S, Ndour PA, Roussel C, Ader F, Safeukui I, Nguyen M, Biligui S, Ciceron L, Mouri O, Kendjo E, Bricaire F, Vray M, Angoulvant A, Mayaux J, haldar K, Mazier D, Danis M, Caumes E, Thellier M, Buffet P; French Artesunate Working Group (2014). Postartesunate delayed hemolysis is a predictable event related to the lifesaving effect of artemisinins. Blood 124(2): 167-75

57. Plewes K, Haider MS, Kingston HW, Yeo TW, Ghose A, Hossain MA, Dondorp AM, Turner GD, Anstey NM (2015). Severe falciparum malaria treated with artesunate complicated by delayed onset haemolysis and acute kidney injury. Malar J 14: 246

58. Fanello $C$, Onyamboko $M$, Lee $S J$, Chotivanich $K$, Buffet $P$, Jaureguiberry $S$, Rockett $K$, Stepniewska K, Day NPJ, White NJ, Dondorp AM (2017). Post-treatment haemolysis in African children with hyperparasitaemic falciparum malaria; a randomized comparison of artesunate and quinine. BMC Infect Dis 17(1): 575

59. Esu E, Effa EE, Opie ON, Uwaoma A, Meremikwu MM (2014). Artemether for severe malaria. Cochrane Database Syst Rev (9): CD010678

60. Esu EB, Effa EE, Opie ON, Meremikwu MM (2019). Artemether for severe malaria. Cochrane Database Syst Rev 6: CD010678

61. Nguyen TH, Day NP, Ly VC,Waller D, Mai NT, Bethell DB, Tran TH, White NJ (1996). Postmalaria neurological syndrome. Lancet 1996 348(9032): 917-21.

62. Ashley EA, Dhorda M, Fairhurst RM, Amaratunga C, Lim P, Suon S, Sreng S, Anderson JM, Mao S, Sam B, Sopha C, Chuor CM, Nguon C, Sovannaroth S, Pukrittayakamee S, Jittamala P, Chotivanich K, Chutasmit K, Suchatsoonthorn C, Runcharoen R, Hien TT, Thuy-Nhien NT, Thanh NV, Phu NH, Htut Y, Han KT, Aye KH, Mokuolu OA, Olaosebikan RR, Flaranmi OO, Mayxay M, Khanthavong M, Hongvanthong B, Newton PN, Onyamboko MA, Fanello Cl, Tshefu AK, Mishra N, Valecha N, Phyo AP, Nosten F, Yi P, Tripura R, Borrmann S, Bashraheil M, Peshu J, Faiz MA, Ghose A, Hossain MA, Samad R, Rahman MR, Hasan MM, Islam A, Miotto O, Amato R, Maclnnis B, Stalker J, Kwiatkowski DP, Bozdech Z, Jeeyapant A, Cheah PY, Sakulthaew T, Chalk J, Inthrarabut B, Silamut K, Lee SJ, Vihokhern B, Kunasol C, Imwong M, Tarning J, Taylor WJ, Yeung S, Woodrow CJ, Flegg JA, Das D, Smith J, Venkatesan M, Plowe CV, Stepniewska K, Guerin PJ, Dondorp AM, Day NP, White NJ; Tracking Resistance to Artemisinin Collaboration (TRAC) (2014). Spread of artemisinin resistance in Plasmodium falciparum malaria. N Engl J Med 371(5): 411-23

63. Plewes K, Kingston HWF, Ghose A, Wattanakul T, Hassan MMU, Haider MS, Dutta PK, Islam MA, Alam S, Jahangir SM, Zahed ASM, Sattar MA, Chowdhury MAH, Herdman MT, Leopold SJ, Ishioka H, Piera KA, Charunwatthana P, Silamut K, Yeo TW, Lee SJ, Mukaka M, Maude RJ, Turner GDH, Faiz MA, Tarning J, Oates JA, Anstey NM, White NJ, Day NPJ, Hossain MA, 
Roberts li L, Dondorp AM (2018). Acetaminophen as a renoprotective adjunctive treatment in patients with severe and moderately severe falciparum malaria: a randomized controlled, open-label trial. Clin Infect Dis 67(7): 991-999

64. Warrell DA, Looareesuwan S, Warrell MJ ,Kasemsam P, Intaraprasert R, Bunnag D, Harinasula $T$ (1982). Dexamethasone proves deleterious in cerebral malaria. A double-blind trial in 100 comatose patients. N Eng/ J Med 306(6): 313-9.

65. Mohanty S, Mishra SK, Patnaik R, Dutt AK, Pradhans S, Das B, Patnaik J, Mohanty AK, Lee SJ, Dondorp AM (2011). Brain swelling and mannitol therapy in adult cerebral malaria: a randomized trial. Clin Infect Dis 53(4): 349-55

66. Tan KR, Wiegand RE, Arguin PM. Exchange transfusion for severe malaria: evidence base and literature review. Clin Infect Dis 57(7): 923-8

67. Calvo-Cano A, Gomez-Juyent J, Lozano M, Castro P, Cid J, Nicolas JM, Quinto L, Martin M, Munoz J, Gascon J (2016). The role of red blood cell exchange for severe imported malaria I the artesunate era: a retrospective cohort study in a referral centre. Malar J 15: 216

68. Kreeftmeijer-Vegter AR, Melo Mde M, de Vries PJ, Koelewijn R, van Hellemond JJ, van Genderen PJ (2014). Manual blood exchange transfusion does not significantly contribute to parasite clearance in artesunate-treated individuals with imported severe Plasmodium falciparum malaria. Malar J 12: 115

69. Church J, Maitland K (2014). Invasive bacterial co-infection in African children with Plasmodium falciparum malaria: a systematic review. BMC Med 12: 31

70. Phu NH, Day NPJ, Tuan PQ, Mai NTH, Chau TTH, Van Chuong L, Vinh H, Loc PP, Sinh DX, Hoa NTT, Waller DJ, Wain J, Jeyapant A, Watson JA, Farrar JJ, Hien TT, Parry CM, White NJ (2020). Concomitant bacteremia in adults with severe falciparum malaria. Clin Infect Dis pii:ciaa191. doi: 10.1093/cid/ciaa191

71. Maitland K, Kiguli S, Opoka RO, Engoru C, Olupot-Olupot P, Akech SO, Nyeko R, Mtove G, Reyburn H, Lang T, Brent B, Evans JA, Tibenderana JK, Crawley J, Russell EC, Levin M, Babiker AG, Gibb DM; FEAST trial Group (2011). Mortality after fluid bolus in African children with severe infection (2011). N Eng/ J Med 364(26): 2483-95

72. Aung NM, Kaung M, Kyi TT, Kyaw MP, Min M, Htet ZW, Anstey NM, Kyi MM, Hanson J (2015). The Safety of a Conservative Fluid Replacement Strategy in Adults Hospitalised with Malaria. PLoS One 10(11): e0143062

73. Ishioka H, Plewes K, Pattnaik R, Kingston HWF, Leopold SJ, Herdman MT, Mahanta K,Mohanty A, Dey C, Alam S, Srinamon K, Mohanty A, Maude RJ, White NJ, Day NPJ, Hossain MA, Faiz MA, Charunwatthana P, Mohanty S, Ghose A, Dondorp AM (2019). Associations between restrictive fluid management and renal function and tissue perfusion in adults with severe falciparum malaria - a prospective observational study. J Infect Dis pii: jiz449

74. Seydel KB, Kampondeni SD, Valim C, Potchen MJ, Milner DA, Muwalo FW, Birbeck GL, Bradley WG, Fox LL, Glover SJ, Hammond CA, Heyderman RS, Chilingulo CA, Molyneux ME, Taylor TE (2015). Brain swelling and death in children with cerebral malaria. N Engl J Med 372: $1126-1137$

75. Mohanty S, Benjamin LA, Majhi M, Panda P, Kampondeni S, Sahu PK, Mohanty A, Mahanta KC, Pattnaik R, Mohanty RR, Joshi S, Mohanty A, Turnbull IW, Dondorp AM, Taylor TE, Wassmer SC (2017). Magnetic resonance imagingof cerebral malaria patients reveals distinct pathogenetic processes in different parts of the brain. mSphere 2(3). Pii: e00193-17

76. Mohanty S, Mishra SK, Patnaik R, Dutt AK, Pradhan S, Das B, Patnaik J, Mohanty AK, Lee SJ, Dondorp AM (2011). Brain swelling and mannitol therapy in adult cerebral malaria: a randomized trial. Clin Infect Dis 53(4): 349-55 
632

633

634

635

636

637

638

639

640

641

642

643

644

645

646

647

648

649

650

652

653

654

655

656

651

77. Phu NH, Hien TT, Mai NT, Chau TT, Chuong LV, Loc PP, Winearls C, Farrar J, White N, Day N (2002). Hemofiltration and peritoneal dialysis in infection-associated acute renal failure in Vietnam. N Engl J Med 2002; 347(12): 895-902

78. Bruneel F, Gachot B, Wolff M, Régnier B, Danis M, Vachon F (2001); Corresponding Group. Resurgence of blackwater fever in long-term European expatriates in Africa: report of 21 cases and review. Clin Infect Dis 32: 1130-1140

79. RTS,S Clinical Trials Partnership. A phase 3 trial of RTS,S/AS01 malaria vaccine in African infants (2012). N Engl J Med 367: 2284-2295.

2

(1)

(1)

(1)

6

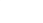

8

0

1

2

3

4

5

47

48

49

50




\section{Compliance with ethical standards}

\section{Conflict of interest statement}

659 None of the authors has a conflict of interest with any of the details shared in the manuscript.

660 All authors contributed to the manuscript.

661

662

663

664

665

666 